Evaluasi: Jurnal manajemen Pendidikan Islam

ISSN (P): 2580-3387, ISSN (E): 2615-2886

DOI : http://doi.org/10.32478/evaluasi.v5i2.741

Article Type : Review Articles

\title{
MANAJEMEN PEMBIAYAAN PENDIDIKAN DITINJAU TAFSIR DAN HADITS TEMATIK
}

\author{
Firdaus Ainul Yaqin*1, Umi Sumbullah*2, Ainur Rofiq*3 \\ ${ }^{1}$ Universitas Islam Zainul Hasan Genggong, Probolinggo Indonesia \\ 2,3Universitas Islam Negeri Maulana Malik Ibrahim, Malang Indonesia
}

Corresponding author: firdoz10@gmail.com

Submission Track:

Submisson : : 14-07-2021

Accept Submission : 08-09-2021

Avaliable Online : :11-09-2021

Copyright @ 2021 Author

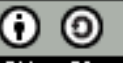

This work is licensed under a Creative Commons Attribution-ShareAlike 4.0

\begin{abstract}
Religion-based education financing, in general, experiences several obstacles in managing education financing, in managing education financing which focuses on the distribution of educational benefits and the burden borne by the community, the amount of money spent or services with the aim of student needs, in a very important case in Education financing is in the form of the amount of money that must be spent, where is the source of the money obtained, and to whom the money should be spent. This research uses a literature study (literature study). The results of this study are Islamic education management is very important to make the activities of the institution operate in accordance with the teachings of Islamic law, namely the Al-Quran and Hadith, and to create a quality educational institution. Islam views education financing which is fully borne by the state. Islamic history shows that so Islamic educational institutions must return to the khittah in managing education financing, just like the Islamic caliphate.
\end{abstract}

Keywords: Management, education financing, Islamic education

\begin{abstract}
Abstrak
Pembiayaan pendidikan berbasis Agama, pada umumnya mengalami beberapa kendala dalam mengelola pembiayaan pendidikan, dalam mengelola pembiayaan pendidikan yang menitikberatkan pada pendistribusian benefit
\end{abstract}


pendidikan dan beban yang ditanggung masyarakat, jumlah nilai uang yang dibelanjakan atau jasa pelayanan dengan tujuan kebutuhan siswa, dalam hal yang sangat penting dalam pembiayaan pendidikan adalah berupa besar uang yang harus dibelanjakan, dari mana sumber uang yang diperoleh, dan kepada siapa uang harus dibelanjakan. Penelitian ini menggunakan studi pustaka (literatur study). Hasil penelitian ini adalah manajemen pendidikan Islam sangat penting untuk menjadikan aktivitas lembaga beroperasi sesuai dengan ajaran syariat Islam, yaitu Al-Quran dan Hadits, dan untuk mewujudkan lembaga pendidikan yang berkualitas. Islam memandang pembiayaan pendidikan yang pembiayaan pendidikan yang ditanggung sepenuhnya oleh Negara. Sejarah Islam menunjukkan, bahwa jadi lembaga pendidikan Islam harus kembali ke khittah dalam mengelola pembiayaan pendidikan, sama seperti khalifah Islam.

Kata Kunci: Manajemen, pembiayaan pendidikan, pendidikan Islam.

\section{A. PENDAhuluan.}

Al-Qur'an dan Hadits sebagai sumber rujukan ajaran agama Islam, dan memiliki kedudukan sangat penting bagi umat Islam, Al-Qur'an dan Hadis-hadist Nabi Muhammad menjelaskan karakteristik ajaran Islam, yang mana tidak mengenal keterlambatan, baik ajaran agama, persoalan dan perkembangan ajaran agama, ekonomi, politik, sosial dan budaya, ataupun persoalan yang tidak lepas dari kehidupan manusia.

Prinsip-prinsip Islam dalam mengenal pembiayaan merupakan penyediaan uang atau tagihan yang dipersamakan, yang mana kesepakatan antara bank dengan pihak lain yang menghendaki pihak yang dibiayai untuk mengembalikan uang atau tagihan, berdasarkan waktu yang telah disepakati atau bagi hasil (Rivai, 2008). Pembiayaan diartikan bentuk pendanaan yang diberikan oleh seorang kepada sesorang lain sebagai bentuk mendukung investasi yang telah disepakati, yang mana dilaksanakan melalui perorangan atau lembaga, dengan kata lain, pembiayaan adalah pendanaan yang dikeluarkan untuk mendukung investasi yang telah direncanakan (Arifin., 2010).

Sejak empat dekade terakhir telah berlangsung pendidikan Islam di Indonesia, terdapat dua pendekatan yang ditempuh: pertama dengan menyesuaikan sepenuhnya pendidikan Islam pada pendidikan Nasional, dengan standarisasi pendidikan Islam sesuai dengan standar Nasional yang dibiyai pemerintah sementara kepemilikan dan administrasi tetap di tangan umat Islam (Sumbulah, 2021). Pendidikan di Indonesia memiliki ketergantungan pada pembiayaan pendidikan, yang mana pembiayaan pendidikan merupakan suatu komponen yang menentukan arah tercapai tujuan pendidikan yang ditelah ditetapkan, Mulyono berpendapat, pembiayaan pendidikan merujuk kepada jumlah uang yang menghasilkan dan dibelanjakan oleh lembaga dengan tujuan menyediakan pendidikan, seperti gaji guru, alat tulis pejabat (ATK), aktivitas mengelola pendidikan, pengawasan pendidikan, dll. Membiayai pendidikan 
merupakan bentuk tanggungjawab utama setiap kegiatan yang berkaitan dengan pernyataan tersebut penulis menyimpulkan pembiayaan pendidikan bermutunya suatu pendidikan di Indonesia dipengaruhi pembiayaan pendidikan (Mulyono, 2010). Bidang pembiayaan membutuhkan pemimpin yang berkompeten dalam mengelola pembiayaan pendidikan, dengan latar belakangan sifat yang jujur agar pengelolaan pembiayaan pendidikan dapat berjalan secara efektif dan efisien. Sesuai dengan sabda Rasulullah SAW yang artinya "Apabila suatu urusan diserahkan kepada yang bukan ahlinya, maka tunggulah masa kehancurannya" H.R. Bukhori, dalam Imam Muslimin (Muslimin, 2013).

Menurut John Pape, 1998 berpendapat bahwa tujuan dari pendidikan tidak hanya sebatas pada pelatihan kerja atau mempersiapkan siswa untuk pekerjaan yang menguntungkan di pasar, akan tetapi tujuan utama mendidik siswa-siswi agar menjadi manusia seutuhnya dan mempersiapkan mereka untuk semua. aspek kehidupan pribadi dan profesional (Donn, 2010). Berdasarkan beberapa pakar pendidikan menyatakan pentingnya peranan pembiayaan pendidikan, negara meluluskan UU Sisdiknas No. 20 tahun 2003, pasal 46 menetapkan bahwa pembiayaan pendidikan adalah tanggungjawab bersama pemerintah, pemerintah daerah dan masyarakat. Kemudian, dalam Pasal 5 (2), juga ditetapkan bahwa pemerintah dan pemerintah daerah berkewajiban untuk memastikan bahwa setiap warga negara yang berusia antara tujuh hingga lima belas tahun diberikan pembiayaan untuk pelaksanaan pendidikan.

Tabel 1.1. : Anggaran Dana BOS tahun 2021

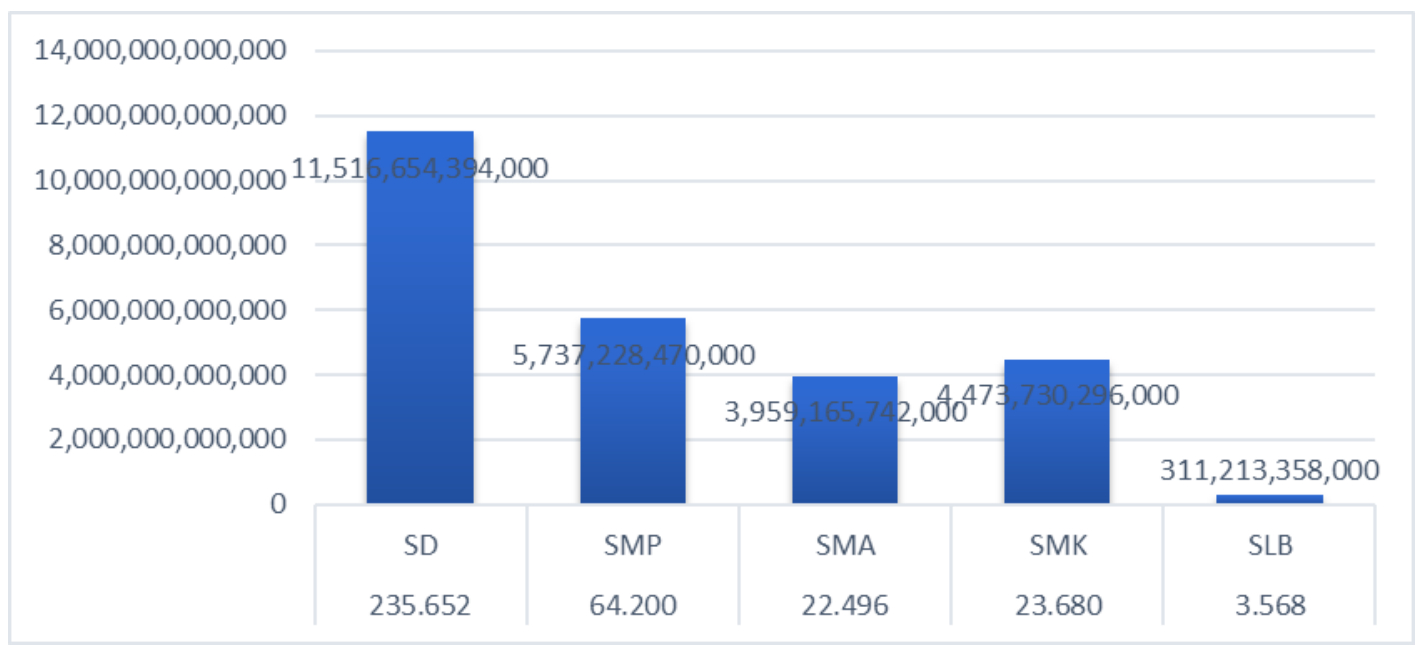

Sumber : Kemendikbud, 2021.

Pedoman BOS 2021 diperbaharui lebih lanjut dalam Permendikbud 6 tahun 2021, dan isinya mencakup bimbingan teknis dalam megelolaan dana BOS. Dana operasional bantuan pada sekolah merupakan pengeluaran belanja non personalia yang dialokasikan kepada satuan pendidikan sekolah dasar dan menengah sebagai 
kewajiban belajar, serta dana untuk mendukung kegiatan operasional yang sesuai dengan peraturan perundaang-undangan.

Pada tahun 2021, Permendikbud No. 6 dalam mengelola dana BOS untuk bantuan operasional sekolah adalah alokasi dana BOS untuk membantu seluruh siswa di sekolah dasar dan menengah untuk memenuhi kebutuhan biaya operasional. Peraturan Menteri Pendidikan dan Kebudayaan No. 6 Tahun 2021 tentang Teknis Pengelolaan Dana BOS secara Berkala diperbaharui setiap tahun. Hal ini dilatarbelakangi oleh peningkatan kualitas pembelajaran dan pemerataan akses pelayanan pada pendidikan. Menyalurkan dana bantuan operasional sekolah dan mendukung operasional sekolah, dalam mengelola dana yang bertujuan agar dapat dipertanggungjawabkan dan akuntabel, dan merumuskan pedoman teknis pengelolaan dana bantuan operasional sekolah reguler.

Program bantuan operasional sekolah terkait pendidikan dasar 9 tahun, setiap pengelola program pendidikan hendaknya memperhatikan hal-hal sebagai berikut: 1) BOS harus menjadi sarana penting untuk meningkatkan mutu pendidikan dasar 9 tahun, 2) BOS tidak boleh terdapat siswa miskin untuk membayar dan berhenti sekolah, 3) anak tamat SD harus melanjutkan pendidikan sekolah ke tingkat SMP 4) kepala sekolah mencari dan mengundang siswa yang akan tamat SD/sederajat, dan dapat diberhentikan sekolah untuk ditampung di SMP/setara, dan mengajak anakanak yang putus sekolah namun masih berminat melanjutkan pendidikan, 5) Kepala sekolah harus mengelola dana BOS secara transparan dan bertanggung jawab. 6) BOS tidak akan menghalangi siswa atau orang tua untuk memberikan sumbangan sukarela dan tidak mengikat sekolah (Mulyono, 2010).

Perhitungan dalam pembiayaan pendidikan, sekolah menggunakan biaya sesuai dana yang dijalankan dalam kegiatan belajar dan mengajar, yang tidak didasarkan pada hubungan dengan dana yang dibutuhkan untuk kegiatan pendanaan berdasarkan kegiatan pembiayaan yang direncanakan preferensi sebelumnya tidak berdasarkan kegiatan yang telah dianggarkan dalam pembiayaan.

Permasalahan yang sering kali timbul disebabkan kurangnya kemampuan manajerial sumber daya manusia dalam pemerintahan dan di sekolah dasar dengan dukungan dana yang tidak memadai atau dana pendanaan, dana ini bukan tujuan yang didasarkan pada kebutuhan siswa dalam pendidikan. Manajemen pendidikan Islam dapat memiliki peran penting untuk sesuai dengan syariat Islam, yaitu Al-Qur'an dan Hadits yang menjadikan lembaga pendidikan yang bermutu berdasarkan beberapa indikator yaitu 1) sesuai yang dibutuhkan pelanggan, 2) pemeliharaan secara terus menerus, 3 ) dan melaksanakan lembaga pendidikan berkualitas menurut beberapa indikator sesuai dengan indikasi tertentu (Sallis, 2005).

Pendidikan manajemen adalah seni dan kerajinan, yang mana dapat diperoleh dalam pembelajaran di kelas sedangkan kerajinan dapat diperoleh dari pengalaman, 
setelah mendapatkan suatu pengalaman, akan menimbulkan rasa untuk mengembangkan ilmu tersebut, sehingga mendalaminya untuk lebih mendalam, oleh karena itu, lulusan manajemen harus bekerja dalam lingkungan yang memiliki tantangan untuk mengembangkan dikarenakan pendidikan manajemen membekali dengan kerangka teori untuk menghadapi tantangan yang berfungsi sebagai pedoman saja, seharusnya manajer dan pemimpin sejati keluar dari dunia korporat yang menantang (Elkaleh, 2017).

Menurut Umemiya, Bidang-bidang yang memastikan kualitas pendidikan tinggi ditentukan berdasarkan yang siswa-siswi dan pendidik institusi akademik memiliki tujuan secara keseluruhan untuk mempromosikan manajemen pendidikan sebagai faktor kunci untuk memastikan proses pembelajaran yang produktif (Umemiya, 2008).

Lisa dan Barbara Rau, menyatakan keyakinan yang kuat dalam mengembangkan hubungan yang lebih erat antara pengajaran dan penelitian, dari kedua komponen tersebut untuk meningkatkan proses pembelajaran dan juga untuk memberikan keterampilan penelitian di antara peserta didik, yang diperumpamakan hari ini peserta didik adalah eksekutif besok, oleh karena itu keterampilan yang diperlukan untuk dunia perusahaan harus dipahat di antara peserta didik (Thomas, 2015). Menurut Datar dalam mengeksplorasi tren yang pendidikan manajemen di Amerika Serikat, para peneliti telah memetakan kurikulum menjadi tiga modul seperti mengetahui komponen, melakukan komponen dan komponen, dan mengamati adanya penyimpangan yang signifikan di antara lulusan manajemen di daerah-daerah seperti mengidentifikasi aktualitas organisasi, keterampilan kepemimpinan, kreatif dan respon inovatif (Datar, 2010).

Pakar ilmuan berpendapat mengenai prinsip-prinsip manajemen pendidikan Islam, terdapat beberapa prinsip dasar manajemen pendidikan Islam diantaranya: Ikhlas, jujur, amanah, adil, tanggung jawab, dinamis, praktis, dan fleksibel (Ramayulis, 2008). Sedangkan pakar lain menyebutkan prinsip dasar manajemen pendidikan Islam dibagi tujuh bagian yaitu : iman dan akhlak, keadilan dan persamaan, musyawarah, pembagian kerja dan tugas, berpegang pada fungsi manajemen, pergaulan dan keikhlasan (Langgulung, 2000).

Sesuai dengan surah Ali Imrān ayat: 75 :

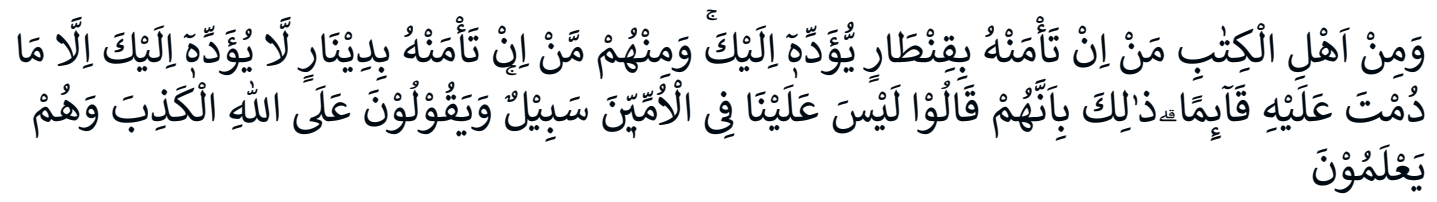

Artinya : Di antara Ahli kitab ada orang yang jika kamu mempercayakan kepadanya harta yang banyak, dikembalikannya kepadamu; dan di antara mereka ada orang yang jika kamu mempercayakan kepadanya satu dinar, tidak dikembalikannya kepadamu kecuali jika kamu selalu menagihnya. Yang demikian 
itu lantaran mereka mengatakan: "tidak ada dosa bagi kami terhadap orangorang ummi. Mereka berkata dusta terhadap Allah, padahal mereka mengetahui. (QS. Ali Imrān : 75) (Agama, 2009).

Asbāb An-Nuzŭl, ayat di atas banyak ditemukan riwayat dalam kitab Al-'ljāb fi AyatAyat Al-Qur'an Tentang Uang dan Pembiayaan Bayān al-Asbāb (asbāb an-nuzŭl), diantarnya:

a. Riwayat Muqātil bin Sulaiman : kelompok pertama, diturunkan kepada orangorang yang beriman dari ahl kitab yaitu Abdullah bin Salam dan kawan-kawan, kelompok kedua, diturunkan kepada orang-orang yahudi dan kawankawannya, diantara mereka ada yang mau menunaikan amanah walau banyak, dan ada juga yang tidak mau menunaikan amanah walau sedikit.

b. Dari Juwaibir bin al-Ḍohhāq dari Ibn 'Abbās : pertama Abdullah bin Salam dititipi 120 auqiyah emas, maka Dia tunaikan amanahnya, dan Allah-pun memujinya, kedua Fanhāṣ bin 'Ȧzŭrā dititipi dinar dari suku quraisy, tapi dia mengkhianatinya.

c. Berkata Al-Tsa'lābi, Menurut para Mufassirin : ayat diatas turun kepada orang Yahudi, dan di maklumi bahwa karakter manusia ada yang amanah dan ada pengkhianat. Allah mengingatkan orang-orang beriman agar berhatihati dengan Ahl al-Kitāb, karena mereka suka mengambil harta orang beriman.

Terdapat beberapa penelitian yang membahas pengaruh manajemen pembiayaan pada tahun 2014 untuk meningkatkan kualitas mutu pendidikan diantaranya Suwarni, dengan judul manajemen pembiayaan dalam peningkatan Mutu Pendidikan di Universitas Dehasen Bengkulu, dalam hasil penelitian: Keputusan pendidikan Bengkulu telah mencapai pembiayaan, tetapi tidak berfungsi dengan baik, tidak baik berarti bahwa itu tidak mendapatkan hasil yang baik, adapaun hasil yang tercapai a) kemampuan pascasarjana yang mendukung di dunia kerja. B) Mendapatkan Etika Profesional yang Baik, C) Berusaha untuk melanjutkan pendidikan ke tingkat yang lebih tinggi.

Swapna Nair, tahun 2018 dalam penelitiannya dengan judul School block grants as a model of financial decentralization in Iraq menemukan bahwa: Memberikan wawasan terperinci tentang modal pengiriman layanan dan saluran pendidikan pembiayaan di Irak di berbagai tingkatan, dalam penelitian ini menyimpulkan model pembiayaan pendidikan terpusat adalah salah satu faktor-faktor yang berkontribusi pada lemahnya tata kelola sekolah dan indikator kinerja sekolah. Ini mengeksplorasi gagasan hibah blok sekolah sebagai model pembiayaan terdesentralisasi dan tinjauan pengalaman negara lain tentang penyediaan hibah blok sekolah memberikan beberapa wawasan menarik tentang apa yang mungkin berhasil untuk Irak (Nair, 2018). 
Eman Elkaleh, tahun 2018 dalam penelitiannya dengan judul Leadership curricula in UAE business and education management programmes A Habermasian analysis within an Islamic context, International Journal of Educational Management, yang menyatakan pendidikan manajemen saat ini membutuhkan pergeseran paradigma untuk memenuhi tuntutan futuristik industri. Institusi pendidikan manajemen harus menganalisis secara menyeluruh tuntutan dalam perspektif di masa depan, dan kebutuhan jam adalah untuk mendesain ulang pendidikan manajemen untuk mengatasi daftar kesenjangan kualitas berikut yang berlaku di pendidikan manajemen, peneliti telah mengambil upaya untuk melakukan studi di India (K.B. Sridevi, 2019).

M. Iqbal, tahun 2019 dengan judul Ayat-Ayat Alqur'an Dan Hadis-Hadis Tematik Tentang Uang dan Pembiayaan, yang menyatakan dinar, dirham dalam al-qu'an dijelaskan sebagai media pertukaran dalam jual beli. Sebagai alat tukar (uang) Qur'an menyebutnya dengan istilah dinar, dirham dan wariq. Dinar dan dirham juga diposisikan sebagai media pertukaran transaksi oleh hadis. Selain itu, dinar dan dirham juga merupakan ukuran atau standar untuk menyatakan harga suatu komoditas (Iqbal, 2019).

Berdasarkan tinjauan penelitian diatas penelitian ini merupakan penelitian pertama yang mendeskripsikan pengelolaan dan aliran dana pembiayaan pendidikan Islam di Indonesia, yang dikaitkan dengan tinjauan Tafsir dan Hadist tematik, terdiri dari penerapan mengelola pembiayaan pendidikan dan beberapa strategi dalam pengelolaan pembiayaan pendidikan untuk menimalisir tejadinya risiko.

\section{B. METODE PENELITIAN}

Penelitian ini menggunakan, pendekatan kualitatif adalah dalam bentuk katakata, skema, dan gambar (Sugiyono, 2013). Penelitian ini menggunakan studi pustaka (literatur study), Penelitian yang dilaksanakan dengan menggunakan literatur (kepustakaan), baik berupa buku, catatan, maupun laporan hasil penelitian dari penelitian terdahulu. Mengembangkan manajemen pembiayaan pendidikan Islam. Teknik pengumpulan data penelitian dari pengembangan lembaga pendidikan Islam dan pengembangan artikel dan buku yang berkaitan dengan manajemen pembiayaan pendidikan (Hasan, 2002).

Analisis data yang digunakan dua teknik, yaitu: pertama analisis deskriptif yaitu upaya untuk mengumpulkan dan meyusun data, kemudian menganalisis data, kedua Analisis data yang bertujuan menganalisis isi dalam bentuk deskriptif. Sementara teknik analisis data menggunakan studi pustaka, menulis dan merangkum semua artikel dan buku dalam pengembangan lembaga pendidikan Islam, dan meninjau buku dan artikel yang terkait dengan data sumber lain yang dipelajari dalam manajemen pembiayaan pendidikan Islam. 


\section{HASIL DAN PEMBAHASAN}

\section{Sejarah Pembiayaan Pendidikan dalam Islam}

Pembiayaan pendidikan dalam Islam, sebagai bentuk tanggung jawa Negara, dalam kaitan ini yang menyangkut infratuktur serta sarana dan prasarana pendidikan dan pembiayaan pendidikan gaji guru atau dosen sepenuhnya menjadi kewajiban negara dengan diberikan fasilitas Nagara (Al-Jawi, 2007).

Tiga tugas pokok kewajiban Negara dalam menjamin dan memenuhi kebutuhan pokok masyarakat, yaitu pendidikan, kesehatan dan keamanan, berbeda dengan kebutuhan pribadi seperti sandang pangan dan papan, yang mana Negara memberikan jaminan secara tidak langsung, tetapi dalam pendidikan, kesehatan dan keamanan, jaminan negara itu secara langsung. Sesuai dalam Nabi Muhamamad SAW bersabda "Imam adalah bagaikan penggembala dan dialah yang bertanggung jawab atas gembalaannya itu". Setelah Perang Badr, beberapa tahanan yang tidak dapat menebus pembebasan, diminta untuk mengajari membaca dan menulis sepuluh anak ke Madinah. Ini menunjukkan bahwa para pemiimpin Islam memperhatikan permasalahan pendidikan Islam.

Berdasarkan ijma' dan sahabat menyimpulkan bahwa Negara memiliki kewajiban menangani pembiayaan pendidikan. Pada saat Khalifah Umar dan Utsman rela memberikan gajinya pada guru, Muadzin dan Imam Sholat Jama'ah, dan pada Khalifah Umar memberikan gaji tersebut dari pendapatan negara yang bersumber dari jizyah, kharaj, dan usyur (Muhammad, 2002).

Penilaian hadits tentang pembiayaan (sanad hadits shohih)

$$
\text { التلخيص الحبير في تخريج أحاديث الرافعي الكبير - (ج } 3 \text { / ص 493) }
$$

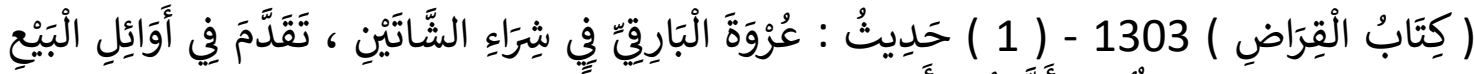

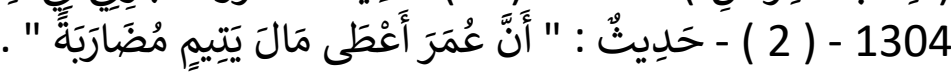

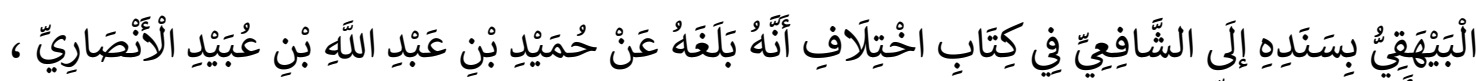

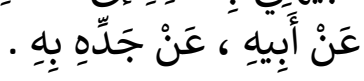

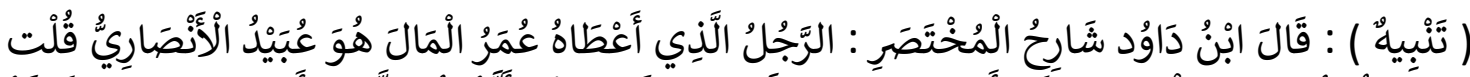

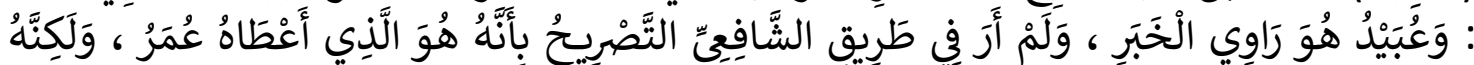

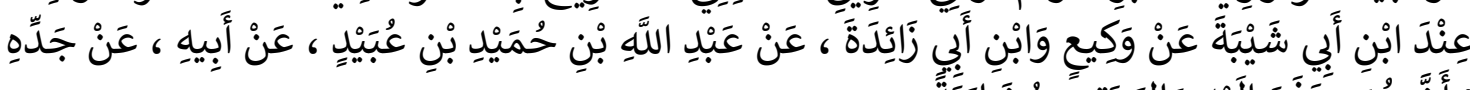

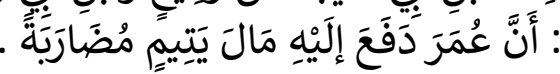

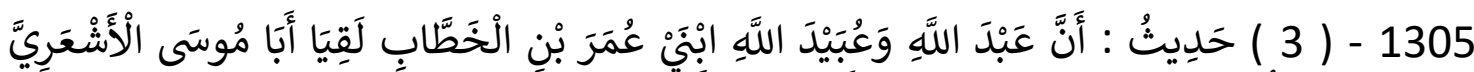

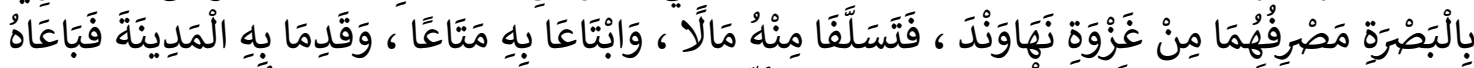

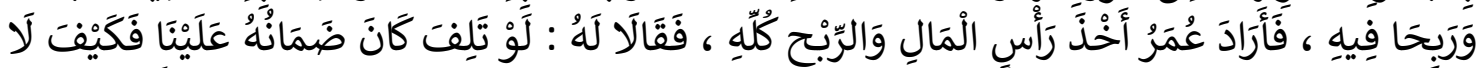

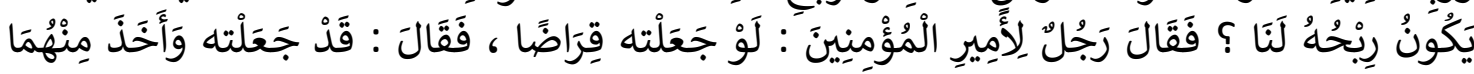


(Kitab tentang pemberian modal) 1303-(1) hadits : dalam hadits arwah al-bariqi dan sungguh telah terdahulu masanya pada bab awal-awal bai' 1304 (2) Hadits: "sesungguhnya umar telah memberikan harta anak yatim Sebagai modal.

Baihaqi sanadnya bersambung pada Imam Syafi'l dalam kitab ikhtilaf, sesungguhnya Baihaqi menyampaikan bahwa humaid bin abdillah bin Ubaid anshori, dari ayahnya, dari kakeknya. (perhatian).Ibnu Daud berkata bahwa ada seorang laki-laki memberikan hartanya umar pada ubaidillah ansori, dia berkata tidak pernah bertemu di Riwayat syafi'l, sesungguhnya harta tersebut diberikan pada umar, akantetapi Ketika inbu abi syaibah dari waqi' dan ibnu abi zaidah, dari abdillah bin humaid bin Ubaid, dari ayahnya, dari kakeknya. sesungguhnya sayyidina umar itu memberikan hartanya anak yatim sebagai mudhorobah (modal)

1305-(3) Hadits : sesungguhnya Abdullah dan Ubaidillah, anaknya Umar bin Khatab bertemu dengan Abu musa Al-Asyari di Bashrah dari perang Nahawan. Maka Abdullah dan Ubaidillah meminjam harta dari Abu Musa Al-As'ari, dan mereka itu menjual harta tersebut. Dan Ketika sesampai di Madinah mereka menjual harta tersebut dengan mengambil seluruh laba Ketika terjual, akan tetapi Ketika tidak terjual maka mereka yang akan mengembalikan seluruhnya. Maka berceritalah seorang laki-laki tersebut pada Amirul mukminin, dan beliau berkata jikalau mendapatkan modal, sebaiknya jika telah laku terjual seluruhnya maka keuntungan seharusnya dibagi setengah untuk penjual dan pemilik modal.

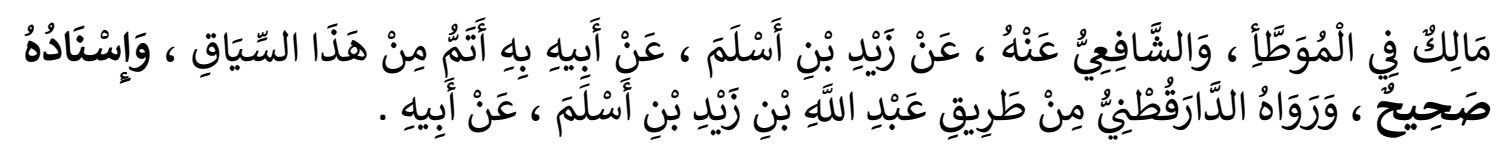

Hadits ini shohih karena rawinya adil, dhobit, sanadnya bersambung, tidak ada syadz, tidak ada ilat

$$
\text { أَوَلَّهَا الصَّحِيحُ وَهْوَ مَا اتََّصَلْ ... إسْنَادُهُ وَلَمْ يَشُذََّّ أَوْ يُعَلْ }
$$

Yang pertama hadits shahih yaitu yang sanadnya bersambung tanpa adanya syadz dan 'illa

$$
\text { يَرْوِيهِ عَدْلٌ ضَابِطُ عَنْ مِثْلِهِ ... مُعْتَمَدْ فِي ضَبْطِهِ وَنَقْلِهِ }
$$

Yang diriwayatkan dari perawi adil dan dhabit dari yang semisalnya yang diakui kedhabitan dan penukilannya 
Sejarah Islam juga mencatat khalifah memiliki kebijakan pendidikan secara gratis untuk masyarkat umum. Sejak abad IV H telah mengembangkan berbagai perguruan tinggi dan berusaha untuk menambahkan semua jenis sarana dan prasarana, seperti perpustakaan. Perguruan tinggi memiliki fasilitas terdapat dengan "Diwan" (Auditorium), penginapan mahasiswa, perumahan dosen dan ulama (Khalid, 1994).

Pendidikan gratis juga tersedia di era Utsmaniyah Khilafah, Sudan Muhammad al-Fatih (W.1481 M). Delapan sekolah dikembangkan di Sudan di Konstantinopel (Istanbul). Hotel mahasiswa telah membangun kamar tidur dan ruang makan di sekolah-sekolah ini. Sudan menawarkan siswa beasiswa bulanan. Membangun perpustakaan khusus mengelola perpustakaan khusus yang dikelola oleh realitas dan pengetahuan yang mendalam.

Pada masa Khilafah Utsmaniyah, menyediakan pendidikan gratis, Sultan (Khalifah) Muhammad Al-Fatih (w. 1481 M). Delapan sekolah dikembangkan di Sudan di Konstantinopel (Istanbul). Di sekolah-sekolah ini dibangun kamar tidur dan ruang makan di sekolah-sekolah ini. Sultan menawarkan siswanya mendapatkan beasiswa bulanan. Membangun perpustakaan khusus mengelola perpustakaan khusus yang dikelola oleh realitas dan pengetahuan yang mendalam (Ash-Shalabi, 2004).

Berdasarkan pernyataan di atas, diketahui bahwa pembiayaan pendidikan merupakan tanggung jawab Negara, tetapi Islam tidak adanya larangan apabila masyarakat memiliki inisiatif melakukan pembayaran, yang dikhususkan bagi yang berpenghasilan diatas rata-rata atau kaya ray. Penerapan waqf telah membuktikan sejarah orang kaya dalam melakukan pembangunan sekolah dan perguruan tinggi, pada setiap kota seperti Damaskus, Baghdad, Kairo, Salsa, dan lainnya dengan mendirikan pembangunan lembaga pendidikan dan perpustakaan berasal dari Waqf (Qahaf, 2005). Wakaf yang bersifat khusus merupakan kegiatan tertentu yang dilakukan sebagian orang, seperti wakaf untuk para ilmuwan, wakaf khusus yang mana dokter, wakaf khusus untuk penelitian medis, guru anak-anak wakaf khusus, Wakaf khusus adalah fiqh dan ilmu sains klasik, serta sejarah memiliki wakaf khusus untuk Syaikh Al -azhar atau fasilitas kendaraan, bahkan wakaf juga diberikan dalam bentuk mahasiswa dan asrama siswa, alat tulis, termasuk beasiswa dan biaya pendidikan (Qahaf, 2005).

Pandangan Islam, Masyarakat harus mendapatkan pendidikan formal yang dijamin oleh Negara, dan melalui konsep wakaf yang bersumber dari masyarakat kaya, maka masyarakat menerima pendidikan informal secara gratis atau murah sebagai masyarakat sekitar (Munir, 2013).

Berbeda dengan penjelasan di atas, menurut sejarah konsep pembiayaan pendidikan Islam, sistem pendidikan formal yang dilakukan Negara Khilafah bersumber pembiayaan dari Negara, pada masa Khalifah Umar bin Khattab, sumber pembiayaan untuk kemaslahatan umum yang berasal dari pajak tanah dan pungutan 
harta non muslim, terdapat dua sumber pendapatan Baitul Mal yang dapat digunakan untuk pembiayaan, yaitu :

1. Fa'i dan kharaj yang merupakan kepemilikan negara, seperti Ghanimah, Khumus.

2. Kepemilikan umum, seperti tambang minyak dan gas, hutan, lautan dan kuda (telah disepakati kepemilikan umum yang telah dikhususkan). Meskipun pendapatan dari pos zakat tidak dapat digunakan untuk pendidikan, dikarenakan Zakat memiliki keperuntukannya sendiri, terbagi dalam delapan kelompok (Zallum, 1990).

Sumber pendapatan tidak dapat dikatakan tercukupi, khawatir akan menimbulkan efek negatif apabila pembiayaan ditunda, negara harus segera memperoleh hutang, dibayar oleh negara dari pengumpulan pajak Islam. Alokasi pembiayaan pendidikan dari Baitul Mal dapat menghabiskan dua unsur kepentingan, pertama membayar semua pihak yang berkaitan dengan layanan pendidikan, seperti guru, dosen, karyawan, dan lainnya. Kedua, membiyai berbagai sarana dan prasarana pendidikan, seperti bangunan sekolah, asrama, perpustakaan, brosur, dan sebagainya (Zallum, 1990).

\section{Penerapan Pembiayaan Pendidikan Ditinjau Tafsir dan Hadits}

Pada dasarnya, setiap sekolah atau madrasah memiliki permasalahan, dalam hal ini sekolah yang berbasis agama permasalahan utama yaitu madrasah, berdasarkan hasil Puslitbang Pendidikan Agama dan Keagamaan, pada tahun 2006 tentang pendanaan pendidikan sekolah yang menunjukkan dana pendidikan sekolah kesulitan dalam penggelolaanya, kendala utama terletak pada terbatasnya sumber daya yang dapat dikelola. Menurut staf pengelola informasi sekolah, sumber dana utama mendapatkannya dari iuran SPP siswa. Sumber dana tersebut adalah pendapatan tetap sekolah, meskipun nominal dana yang terkumpul sebenarnya tidak dapat menutupi pengeluaran biaya sekolah, karena sebagian besar letak sekolah di pinggiran atau pedesaan dan memberikan pendidikan kepada siswa dari keluarga kurang mampu, seperti petani, pekerja dan pekerja tingkat rendah lainnya (Hasil penelitian Puslitbang Pendidikan Agama Dan Keagamaan, 2006). SPP madrasah sebagai sumber dana sekolah, terkait jumlah angsuran SPP besarannya madrasah atau sekolah disesuaikan kondisi sosial ekonomi masyarakat sekitar sekolah dan madrasah atau sekolah juga menetapkan besaran biaya SPP.

Selain biaya pendidikan, sumber pendanaan lainnya adalah bantuan masyarakat berupa zakat, infaq dan shadaqah. Sumber pendanaan ZISWAF relatif tidak stabil, mengingat ada beberapa masalah dalam pengelolaan dan pendistribusiannya, sehingga tidak dapat menentukan jumlah dan keberadaannya. Bantuan tambahan lainnya diberikan oleh pemerintah dan pemerintah daerah, seperti hibah khusus, dana swadaya, BOMM, BOP, BKG, dan BKS. Selain bersifat insidential dan tidak lengkap, tidak semua sekolah dapat menerimanya (Munir, 
Manajemen Pembiayaan Pendidikan dalam Perspektif Islam, 2013). Biasanya, bantuan ini didapat setelah madrasah mengajukan permohonan ke pemerintah daerah. Selain itu, di antara berbagai kasus yang terjadi di berbagai provinsi, hanya beberapa madrasah yang menerimanya. Dalam hal ini, kedekatan antara penyelenggara madrasah dengan pemerintah daerah sangat mempengaruhi kelancaran penyaluran bantuan (Nunu, 2007).

Permasalahan sumber daya manusia tidak bisa dikatakan sebagai memadai, ditambah dengan terbatasnya pengetahuan tentang sirkulasi dan pengaturan anggaran pembiayaan, pengaturan anggaran yang tidak baik akan berdampak pada kurangnya analisis jangka panjang tentang bagaimana, mengapa, dalam hal ini mengakibatkan tidak ada upaya untuk mencari dan mengembangkan peluang. Pada akhirnya, lembaga atau sekolah tersebut bersifat eksklusif dan hanya bisa mengandalkan dana pemerintah.

Dalam tafsir Al-Lubāb fi al-'Ulŭm Al-qur'an , yang dimaksud dengan Qinthori adalah yang banyak, sedangkan Dinaarin adalah sesuatu yang sedikit, yakni ada orang-orang dari ahl kitab yang sangat tidak amanah (penghianat) walau sedikitpun diberi amanah.

Surah Ali Imrān ayat: 14 :

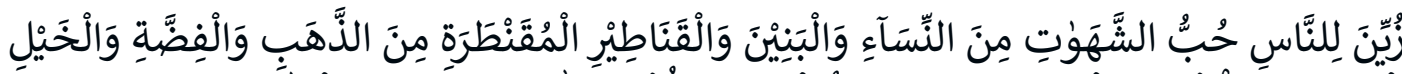

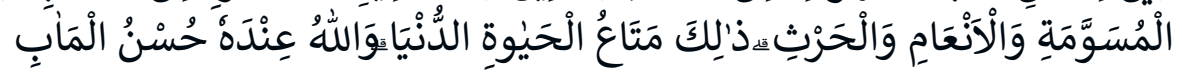

Artinya : Dijadikan indah pada (pandangan) manusia kecintaan kepada apa-apa yang diingini, yaitu: wanita-wanita, anakanak, harta yang banyak dari jenis emas, perak, kuda pilihan, binatang-binatang ternak dan sawah ladang. Itulah kesenangan hidup di dunia, dan di sisi Allah-lah tempat kembali yang baik (surga). (QS. Ali Imrān :14)

Munāsabah ayat, ketika Allah menceritakan kondisi orang-orang beriman dengan do'a mereka agar diteguhkan dalam keimanan, kemudia di ceritakan bagaimana cerita orang kafir, dan yang menyebabkan kekufuran mereka, karena terpedaya dengan kehidupan dunia, banyaknya harta, dan keturunan.

Menurut Ibn Hajar dalam karyanya Al- 'Ijāb fi Bayān al-Asbāb (asbāb an-nuzŭl), ada dua riwayat :

a. Riwayat Ibn Z̧ofar, bahwa ayat di atas turun ketika delegasi Najran datang ke Madinah dengan pakaian yang serba indah, sehingga muncul ketertarikan pemuda-pemuda dari orang-orang miskin orang Islam.

b. Berkata Ibn Ishāq dari Muhammad bin Ja'far bin alJubair : ketika masuk masjid waktu ashr rombongan kabilah bani Haris dengan pakaian jubah berwarna hitam yang bagus. 
Masalah lain yang sering muncul dari dukungan masyarakat sekitar yang relatif rendah. Masyarakat adalah peserta dan penggerak keberhasilan proyek lembaga pendidikan. Keberadaannya sangat penting untuk mendukung pembiayaan pendidikan, karena berawal dari kurangnya transparansi di masyarakat dan tidak ikut serta secara langsung dalam proses penganggaran, sehingga perhatian masyarakat terhadap lembaga tersebut berhenti di daerah-daerah yang meninggalkan masyarakat.

التلخيص الحبير في تخريج أحاديث الرافي الكبير - (ج 3 / ص 138)

$$
\text { كتاب الْقِرَاضِ }
$$

حَدِيثُ عُرْوَةَ "الْبَارِقِيِّ فِي شِرَاءِ الشَّاتَيْنِ" تَقَلََّمَ فِي أَوَائِلِ الْبَيْعِ

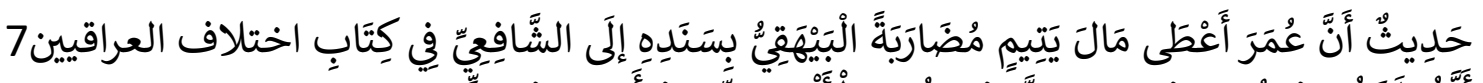

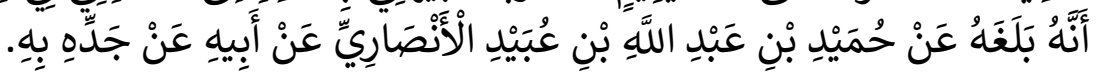

\section{Kesimpulan yang didalam takhrij hadits Al-Kabir Juz 3, Halaman 138}

Kitab tentang qirad

Hadits ruwah al bariqi tentang membeli dua ekor kambing, telah lalu pembahasannya dalam awal-awal bab bai', ada hadits bahwa sesungguhnya sayyidina umar itu memberikan hartanya anak yatim sebagai mudhorobah (modal), hadits ini sesuai dari Baihaqy dengan sanad Imam syafii, dalam kitab ihtilafil Aroqin, bahwasanya hal itu disampaikan dari al-humaidi, dari ayahnya Abdillah, dari kakeknya Ubaidil Anshori, dari ayahnya dari kakeknya.

\section{Beberapa jalur hadits}

$$
\text { الدراية في تخريج أحاديث الهداية - (ج } 2 \text { / ص 181) }
$$

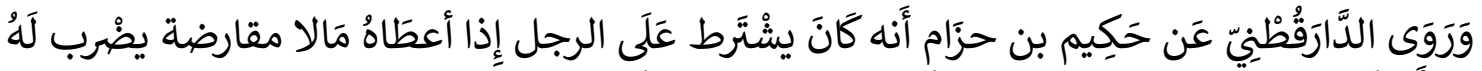

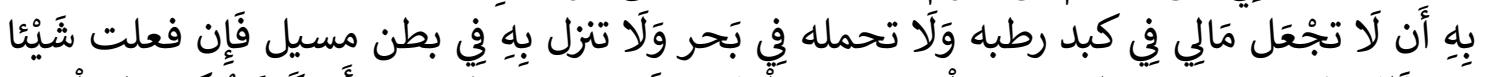

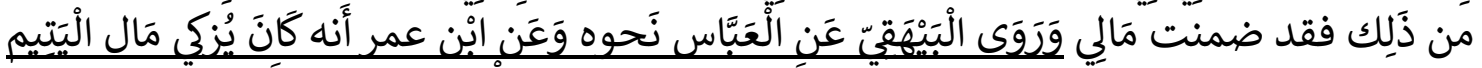

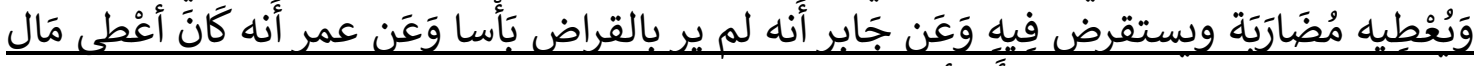

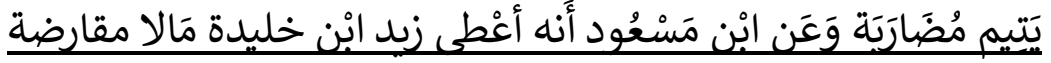

Hadits tentang pembiayaan ini melalui jalur sanad Ibnu Abbas, Ibnu Umar, Jabir, Umar, Ibnu Mas`ud

\section{Beberapa redaksi hadits}

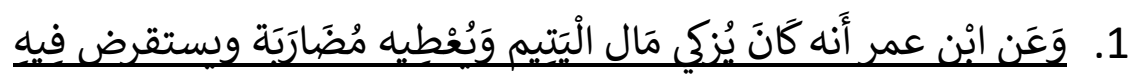




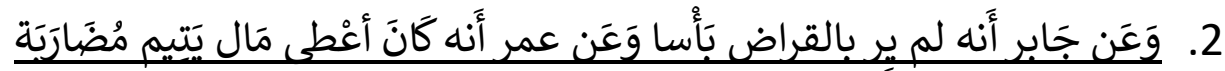

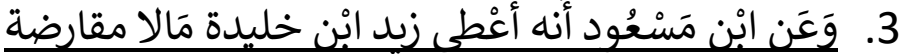

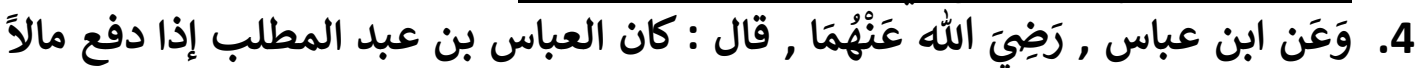

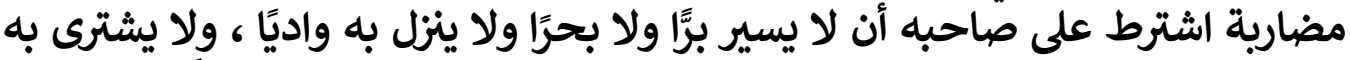

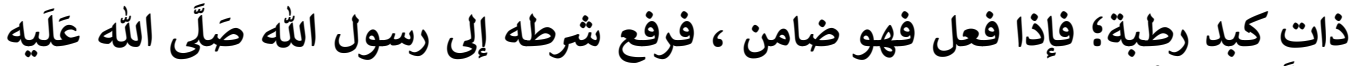

\section{Rawi jalur ibnu masud}

$$
\text { وسَلَّم بين فأجازه. }
$$

$$
\text { التلخيص الحبير في تخريج أحاديث الرافي الكبير - (ج } 3 \text { / ص 140) }
$$

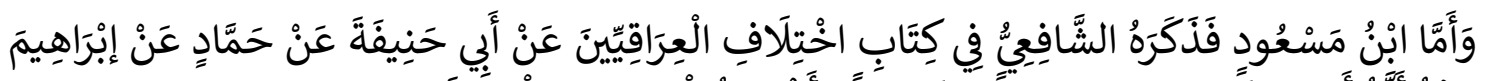

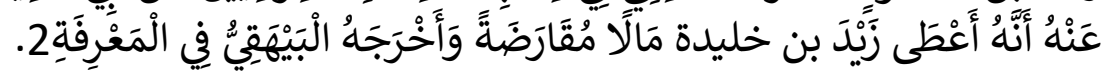

\section{Kesimpulan yang didalam takhrij hadits Al-Kabir Juz 3, Halaman 140}

Diriwayatkan dari ibnu mas'ud dengan bersumber dari Imam Syafi'l dalam kitab ihtilafil Iraqin, dari Abu Hanifah dari Hammad dari Ibrahim bahwasanya Zaid bin Khalidah memberikan harta qard. Dikeluarkan oleh Baihaqi dalam

Rawi jalur ibnu abbas

$$
\text { التلخيص الحبير في تخريج أحاديث الرافعي الكبير - (ج } 3 \text { / ص 140) }
$$

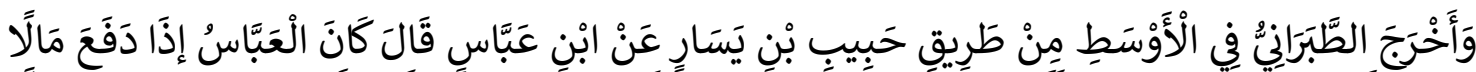

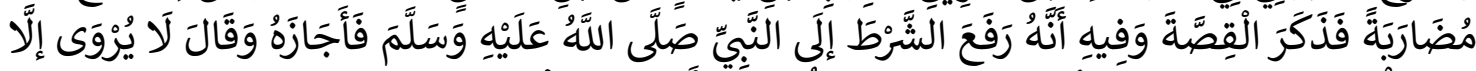

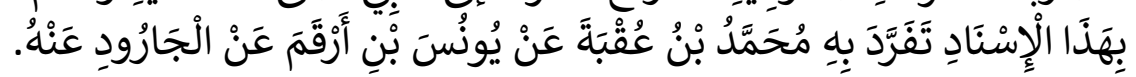

\section{Kesimpulan yang didalam takhrij hadits Al-Kabir Juz 3, Halaman 140}

diriwayatkan oleh Thabrani dari pertengahan riwayat habib bin yasar dari ibnu abbas berkata ketika Abbas menolak dalam perkara mudhorobah maka ia teringat dengan kisah yang mana rasulullah telah membolehkan akan adanya mudhorobah,. dalam hal ini tidak ada riwayat lain kecuali yang diriwayatkan oleh Ibnu Abbas

Takhrij Hadits Pembiayaan (MUDHORABAH)

البدر المنير في تخريج الأحاديث والأثار الواقعة في الشرح الكبير - (ج 7 / ص (21)

$$
\text { كتاب الْقَرَاض }
$$

ذكر فِيهِ حَدِيث عُرْوَة الْبَارِقِي وَقد سلف فِي أَوَائلِ البيع ، وَذكر فِيهِ أَيْضا آثارًا. 


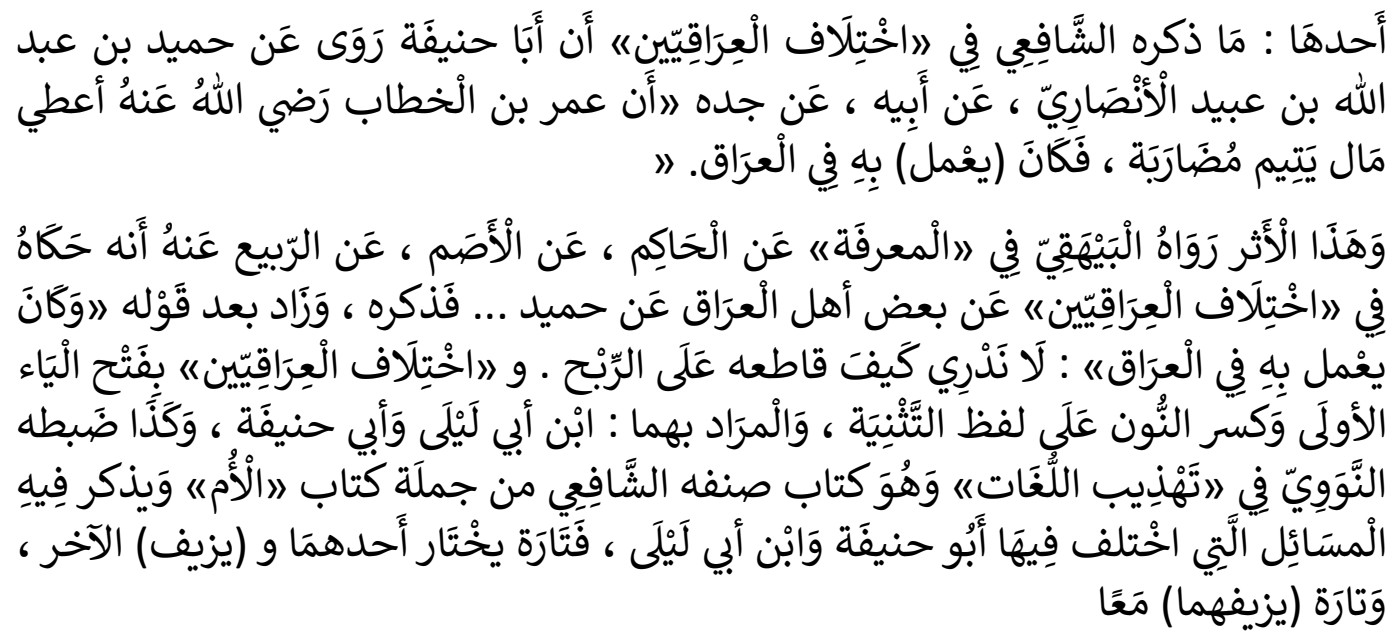
Artinya :

Purnama yang terang didalam takhrij hadits yang terdapat dalam kitab syarh Kabir jus 7 halaman 21, ini tentang bahasan qird (pemberian modal) disebutkan dalam hadits arwah al-bariqi dan sungguh telah terdahulu masanya pada bab awal-awal bai', dan juga disebutkan beberapa atsar.

Salah satunya adalah keterangan yang disebutkan oleh Imam AsSyafii, tentang perbedaan dua orang Iraq, bahwa sesungguhnya abu hanifa itu meriwayatkan dari ayahnya, dari kakeknya, sesungguhnya umar bin khattab yaitu telah memberikan harta anak yatim Sebagai modal, dan ada umar bin khattab itu melakukan hal ini di Iraq. Dan atsar ini diriwayatkan oleh al-Baihaqy dalam kitab al-Ma'rifah dari ibnu al-hakim, dari ibnu ashom dari ibnu rabi', bahwa diceritakan dalam pembahasan itu dari Sebagian ahlu Iraq, dari humaidi beliau menyebutkan dan beliau juga menambahkan hal tersebut dilakukan di Iraq. Kamu tidak mengetahui bagaimana dia tidak memutus tentang laba. Adapun dengan memfathahkan ya' yang pertama, dan mengkasrohkan nun, berdasarkan lafadz tasniyah, berlafadzkan dua. Adapun yang dimaksut antara keduanya yakni ibnu abi laili dan abu hanifah dua orang Iraq itu.

Kemudian imam an-nawawi juga memberikan standarisasi didalam kitab tahdzibul lughat, dan kitab ini dikarang imam syafii termasuk juga dari segi jumlah kitab al-umm. Dalam kitab ini tahdzibul lughat ini disebutkan tentang problematika, dimana disana terdapat perselisihan antara abu hanifah dan abu laili, memilih pendapat salah satu dari keduanya dan dengan mendengarkan pendapat yang lain dan terkadang ia meninggalkan pendapat kedua-duanya 
Berdasarkan permasalahan pembiayaan pendidikan Islam, maka penulis mencoba menuliskan beberapa langkah-langkah dalam minimalisir terjadinya risiko pembiayaan pendidikan Islam, Pertama, menyusun pengembangan model pembiayaan pendidikan (Kurniady, 2011). permasalahan dalam pembiayaan merupakan pembahasan sensitif keberadaannya, dikarenakan mengelola pembiayaan pendidikan dapat membawa respon positif pada lembaga apabila dikelola dengan baik, akan tetapi berbanding sebaliknya, akan memiliki respon negatif pada lembaga menjadi terpuruk, maka dalam mengelola dana tersebut dilakukan secara profesional dan melakukan secara tranparansi, dan tidak memiliki niat demi kepentingan untuk personal pribadi, oleh karena itu, dalam mengelola pembiayaan pendidikan

Melibatkan seluruh komponen lembaga pendidikan yang ada, yang menyangkut proses menyusun dana pendidikan, untuk mencapai prinsip keterbukaan, kebersamaan, dan tanggung jawab atas tugas kelembagaan yang harus dibagi, maka memerlukan berbagai sumber dukungan yang tersedia, termasuk dana, perlu diciptakan manajemen organisasi, kepala sekolah, Hubungan antara guru dan komite sekolah dapat merencanakan dan menentukan berbagai rencana atau kegiatan yang diprioritaskan untuk menghasilkan hasil belajar yang memenuhi kebutuhan belajar siswa, sehingga menciptakan lembaga yang baik dan buruk terwujudnya akuntabilitas, dan pada dasarnya mengembangkan model pembiayaan pendidikan, memberikan solusi atas permasalahan dalam pengelolaan pembiayaan pendidikan.

Kedua, dari segi alokasi dana, pengelola pembiayaan pendidikan Islam mampu mempersiapkan dan mengelola, baik penyusunan anggaran, pengeluaran atau anggaran yang ada, dan sistem pelaporan yang ada, dalam hal ini, kasus mencakup apa yang harus dipahami dan diketahui sekolah tentang biaya. Apa tujuannya, berapa sebenarnya biaya PBM, dan kegiatan apa yang perlu didanai untuk mengalokasikan dan mengalokasikan dana secara efektif dan efisien, serta dapat dijelaskan (Kurniady, 2011). Jika komponen yang bertanggung jawab dalam pengelolaan dana tidak memahami tanggung jawabnya, maka harus melakukan pelatihan tentang cara membuat perkiraan, serta pelatihan tentang penganggaran atau hal serupa lainnya.

Ketiga Kepala sekolah adalah penggerak dan harus memiliki kemampuan berwirausaha (entrepreneurial skills) serta kemampuan manajerial dan pengawasan, harus saling koordinasi antara kepala sekolah dengan komite sekolah untuk mencegah penyalahgunaan dana oleh sekolah. Organisasi ini berfungsi sebagai pendorong model untuk memainkan peran penting dalam pengalokasian dana secara efektif dan efisien sehingga PBM memenuhi kebutuhan belajar siswa.

Keempat, sekolah atau madrasah harus melibatkan masyarakat dalam penganggaran dana pendidikan dan menetapkan kebijakan pendanaan untuk meningkatkan kesadaran dan menggali sumber pendanaan untuk menciptakan kerjasama pemerintah-masyarakat, tidak hanya bagi pengelola sekolah dan bentuk 
saran masyarakat yang transparan, evaluasi merupakan proses peninjauan kembali pelaksanaan pengelolaan pembiayaan pendidikan berdasarkan kebutuhan pembelajaran, untuk mengetahui kelebihan, kekurangan, tantangan dan keberhasilan pengelolaan pembiayaan yang dilaksanakan (Kurniady, 2011).

Kelima, lembaga pendidikan Islam, sebagai lembaga Islam yang berbasis agama, memiliki nilai-nilai yang tinggi dan harus menjunjung tinggi prinsip keadilan, amanah, kejujuran, kehati-hatian, keterbukaan, disiplin, dan lain-lain. Semua elemen lembaga harus berpegang teguh pada prinsip-prinsip tersebut, oleh karena itu diharapkan muncul solusi dari masalah pengelolaan pembiayaan pendidikan Islam, sehingga terbentuk lembaga pendidikan Islam yang baik.

\section{KESIMPULAN}

Manajemen pendidikan Islam penting dipelajari supaya aktivitas kelembagaan berjalan sesuai dengan ajaran syariat Islam yaitu Al-Qur'an dan Hadis serta menjadikan lembaga pendidikan yang bermutu, konsep pembiayaan pendidikan Islam, dilakukan Negara Khilafah bersumber pembiayaan dari Negara, pada masa Khalifah Umar bin Khattab, sumber pembiayaan untuk kemaslahatan umum yang berasal dari pajak tanah dan pungutan harta non muslim, terdapat dua sumber pendapatan Baitul Mal yang dapat digunakan untuk pembiayaan, Islam memandang pembiayaan pendidikan yang diselenggarakan negara, sepenuhnya ditanggung oleh Negara. Sejarah Islam telah menunjukkan pembiayaan pendidikan, maka lembaga pendidikan Islam seharusnya kembali kepada khittah pengelolaan pembiayaan pendidikan sebagaimana sudah dicontohkan oleh para khalifah di kekhilafahan Islam.

\section{REFERENSI}

Agama, D. (2009). Al-Qurán dan Terjemah. Bandung: Hilal.

Al-Jawi, S. (2007). Pembiayaan Pendidikan Dalam Islam. Jurnal House of Khilafah, 1.

Arifin., R. V. (2010). Islamic Banking: Sebuah teori, konsep, dan aplikasi. Jakarta: Bumi Aksara.

Ash-Shalabi, A. M. (2004). Bangkit dan Runtuhnya Khilafah Utsmaniyah (AdDawlah AlUtsmaniyah Awamil al- Nuhudh wa Asbab as-Suquth), Penerjemah Samson Rahman,. Jakarta: Pustaka Al-Kautsar.

Datar, S. G. (2010). Business Education at a Crossroads . Boston: Harvard Business Press. 
Donn, G. a. (2010). Globalisation and Higher Education in the Arab Gulf States. Oxford: Symposium Books.

Elkaleh, E. (2017). Leadership curricula in UAE business and education management programmes A Habermasian analysis within an Islamic context . International Journal of Educational Management.

Hasan, M. I. (2002). Pokok-pokok Materi Metodologi Penelitian dan Aplikasinya. Bogor: Ghalia Indonesia .

Iqbal, M. (2019). Ayat-Ayat Alqur'an Dan Hadis-Hadis Tematik Tentang Uang dan Pembiayaan. Aghniya Jurnal Ekonomi Islam, Vol. 1. Nomor.2. Juni .

K.B. Sridevi. (2019). Filling the quality gaps for a futuristic management education. Journal of Economic and Administrative Sciences.

Khalid. (1994). Abdurrahman Muhammad, Soal Jawab Seputar Gerakan Islam. Bogor: Pustaka Thariqul Izzah.

Kurniady, D. A. (2011). Pengelolaan Pembiayaan Sekolah Dasar Di Kabupaten Bandung. Jurnal Penelitian Pendidikan, Vol. 12 No. 1 April .

Langgulung, H. (2000). Asa-asa Pendidikan Islam. Jakarta: Al-Husna Zikra.

Muhammad, Q. I. (2002). Kebijakan Ekonomi Umar bin Khaththab (As-Siayasah AlMaliyah Li 'Umar bin Khaththab), Penerjemah Ahmad Syarifuddin Shaleh, . Jakarta: Pustaka Azzam.

Mulyono. (2010). Konsep Pembiayaan Pendidikan. . Jogjakarta: : Ar-Ruzz Media.

Mulyono. (n.d.). Konsep Pembiayaan Pendidikan . Jogjakarta: Ar-Ruzz Media.

Munir, A. (2013). Manajemen Pembiayaan Pendidikan dalam Perspektif Islam. Jurnal At-Ta'dib , Vo.08, No.2 .

Munir, A. (2013). Manajemen Pembiayaan Pendidikan dalam Perspektif Islam, . Jurnal At-Ta'dib, Vo.08, No.2.

Muslimin, I. (2013). Pemimpin Perubahan Model Kepemimpinan dalam Transisi Perubahan Kelembagaan. Malang: UIN Maliki Press.

Nair, S. (2018). School block grants as a model of financial decentralization in Iraq. International Journal of Comparative Education and Development, Vol. 20 No. $3 / 4$.

Nunu, A. (2007). Pembiayaan Pendidikan di Madrasah dan Peranan Pemerintah Daerah di Era Otonomi. Jurnal Penelitian Pendidikan Agama Dan Keagamaan, Volume 5 Nomer 2 April-Juni . 
Qahaf, M. (2005). Manajemen Wakaf Produktif (Al-Waqf Al-Islami Tathawwuruhu Idaratuhu Tanmiyatuhu), Penerjemah Muhyiddin Mas Rida,. Jakarta: Khalifa.

Ramayulis. (2008). IImu Pendidikan Islam,. Jakarta: Kalam Mulia.

RI, D. A. (2009). Al-Qurán dan Terjemah, . Bandung: Hilal.

Rivai, V. (2008). Islamic Financial Management, Teori, Konsep dan Aplikasi Panduan Praktis Untuk Lembaga Keuangan, Nasabah, Praktisi, dan Mahasiswa. Jakarta: PT Raja Grafindo Persada.

Sallis, E. (2005). Total Quality Management in Education . London: Kogan Page Limited.

Sugiyono. (2013). Metode Penelitian Kuantitatif Kualitatif dan R\&D. Bandung: Alfabeta h.

Sumbulah, U. \&. (2021). Pendidikan Multikultural Dalam Transformasi Lembaga Pendidikan Islam Di Indonesia. Evaluasi: Jurnal Manajemen Pendidikan Islam, 5(1), 128-147.

tahun, H. p. (2006.).

Thomas, D. (2015). Responsible management education for a sustainable world. Journal of Management Development, Vol. 34 No. 1, pp. 16-3.

Umemiya, N. ". (2008). Regional quality assurance activity in higher education in Southeast Asia: its characteristics and driving forces. Quality in Higher Education, Vol. 14 No. 3, pp. 277-290.

Zallum, A. Q. (1990). Al-Amwal fi Daulah Al-Khilafahdan Taqiyuddin An Nabhani, AnNizham Al-lqtishadi fi Al-Islam,. Beirut: Darul Ummah. 